Journal of Animal and Veterinary Advances 11 (6): 781-784, 2012

ISSN: $1680-5593$

(C) Medwell Journals, 2012

\title{
Detection of the Major Macrolide Resistance Genes in Streptococcus suis Serotype 2 Isolates in Hebei Province China
}

\author{
${ }^{1}$ Ping Rui, ${ }^{1}$ PeiGuo Li, ${ }^{1}$ Zengjun Ma ${ }^{2}$ QinYe Song, ${ }^{1}$ CaiRan Yang, \\ ${ }^{1}$ Ping Shen, ${ }^{1}$ SuMin Pan and ${ }^{1}$ Yufang Guo \\ ${ }^{1}$ Key Laboratory of Perventive Veterinary Medicine of Hebei, \\ Hebei Normal University of Science and Technology, 066004 Qinhuangdao, China \\ ${ }^{2}$ College of Animal Science and Technology, Hebei Agricultural University, 071001 Baoding, China
}

\begin{abstract}
To investigate the distribution of ermB, ermA and mefA related to the erythromycin resistance gene, 32 drug-resistant Streptococcus suis type 2 isolates from different areas in Hebei province were studied to detect the ermB, erm $A$ and mefA genes by PCR amplification. The results showed that among the drug-resistant 32 strains, $100 \%$ (32/32) amplified ermB gene, 21.88\% (7/32) isolates contained erm $A$ gene and none of these strains was positive for $m e f A$ gene. The researchers concluded that erythromycin resistance mechanism of pig Streptococcus isolates is mainly mediated by ermB gene. Nucleotide sequences comparison showed that the ermB gene of 20 strains and the nucleotide sequences in the GenBank had the sequence similarity of 95-100\%. Compared with the reference sequence of AJ972604.1, Ser to Asn mutation at position 100 and Arg to His mutation at position 118 of ermB was mainly detected in the 20 strains. The researchers concluded that the $e r m B$ gene is relatively stable.
\end{abstract}

Key words: Pigs, streptococcus, macrolides antibiotics, drug-resistance genes, GenBank, China

\section{INTRODUCTION}

Swine streptococcosis is a pleomorphism epidemic which is caused by a variety of hemolytic Streptococcus and it is common in the world. Some Streptococcus suis serotype 2 (SS2) is a significant pathogen of animals and human beings. With the development of pig industry, swine streptococcosis is more and more popular with the raising management level (especially, swine streptococcosis often occurs in primary or secondary to viral diseases such as porcine reproductive and respiratory syndrome, swine fever and pig wreath virus. With the high morbidity and mortality, it often leads to large economic losses in pig breeding).

In recent years, SS2 appears resistant to antibiotics in different degrees with the improper use of antibiotics. Therefore, it is necessary to study the drug-resistance mechanism of SS2 in the province which has much practical significance. In this study, researchers detected the main resistance genes of erm , ermB, mefA in macrolide-resistant SS2 isolates from pigs by $\mathrm{PCR}$ amplification, compared the homology of main resistant gene sequences. The purpose was to illustrate the macrolide-resistance mechanism of pig Streptococcus isolates in Hebei province and the relationship between the ermB gene mutations or amino acids mutations and different levels of resistance and offers a better guidance for clinical treatment on pig Streptococcus disease, especially in the selection of drugs.

\section{MATERIALS AND METHODS}

Bacterial strains: The $40 \mathrm{SS} 2$ strains were isolated from pigs in Qinhuangdao, Tangshan, Zhangjiakou, Shijiazhuang, Handan in Hebei province during 2005-2011, saved in the Key Laboratory of Preventive Veterinary of Hebei province. The strains were mainly collected from tissues including lung, spleen, kidney, blood of heart, brain, joint fluid and lymph nodes.

Main agents: Taq DNA polymerase (plus) $\left(2 \mathrm{U} \mu \mathrm{L}^{-1}\right)$,

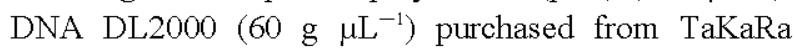
company; AGAROSE, purchased from OXOID company; three hydroxyl methyl carbamate methane (TriS) and sodium ethylenediamine tetraacetate $\left(\mathrm{Na}_{2} \mathrm{EDTA} \cdot 2 \mathrm{H}_{2} \mathrm{O}\right)$ (99.9\%) from Beijing Solarbio Science and Technology Co., Ltd.; Goldview and DNA fast recovery kit (SDS Genetech Co., Ltd.).

Corresponding Author: Zengjun Ma, Key Laboratory of Perventive Veterinary Medicine of Hebei, Hebei Normal University of Science and Technology, 066004 Qinhuangdao, China 
Table 1: PCR primers of resistance genes used in this study

\begin{tabular}{llcc} 
Name & Primer sequence 5'-3' & $\begin{array}{c}\text { Annealing } \\
\text { temp. }\left({ }^{\circ} \mathrm{C}\right)\end{array}$ & $\begin{array}{l}\text { Size } \\
(\mathrm{bp})\end{array}$ \\
\hline ermB & P1: GAAAAGGTACTCAACCAAATA & 55 & 640 \\
& P2: AGTAACGGTACTTAAATTGTTAC & & \\
ermA & P3: GTTCAAGAACAATCAATACAGAG & 52 & 421 \\
& P4: GGATCAGGAAAAGGACATTTTAC & & \\
$m e f A$ & P5: AGTATCATTAATCACTAGTGC & 58 & 346 \\
& P6: TTCTTCTGGTACTAAAAGTGG & & \\
\hline
\end{tabular}

Primer design and synthesis: Primers were designed accroding to the reference (Tait-Kamradt et al., 1997; Sutcliffe et al., 1996) and the GenBank, drug-resistant genetic sequences are designed, respectively and synthesized in Sangon Biotech (Shanghai) Co., Ltd. The details of the primers were shown in Table 1.

External medicine sensitivity test: To detect the Minimum Inhibitive Concentrations (MICs) of marolides such as erythromycin, roxithromycin, azithromycin, tylosin and tilmicosin were used. The 40 isolates were detected by using the method of trace dilution. The specific operation and the comments of the results are according to NCCLS Standard in 2005.

The preparation of PCR template: The genomic DNAs were extracted by Poaching method and then were stored at $-20^{\circ} \mathrm{C}$

The amplication of ermB, erm $A, \operatorname{mef} A$ by PCR: With the chromosomal DNA templates, 32 isolates from pigs were studied to detect the ermB, ermA and mefA using the primers. The Polymerase Chain Reaction (PCR) System $(25 \mu \mathrm{L})$ are as follows: $10 \times \mathrm{PCR}$ buffer $\left(\mathrm{Mg}^{2+}\right.$ Plus ) $2.5 \mu \mathrm{L}$, dNTPs mixture $\left(2.5 \mathrm{mmol} \mathrm{L}^{-1}\right) 2 \mu \mathrm{L}$, the upstream and downstream primers (each) $0.5 \mu \mathrm{L}$, DNA polymerase $0.4 \mu \mathrm{L}$, DNA template $2 \mu \mathrm{L}, \mathrm{ddH}_{2} \mathrm{O} 17.1 \mu \mathrm{L}$. The amplification condition: predegeneration at $93^{\circ} \mathrm{C}$ for $3 \mathrm{~min}$, degeneration at $93^{\circ} \mathrm{C}$ for $45 \mathrm{sec}$, annealing at $52-58^{\circ} \mathrm{C}$ for $45 \mathrm{sec}$, extendence at $72^{\circ} \mathrm{C}$ for $45 \mathrm{sec}$, repeated for 35 cycles.

The last cycle was finished, they were extended at $72^{\circ} \mathrm{C}$ for $10 \mathrm{~min}$. The amplification products were observed by agarose gel electrophoresis.

Recycling of amplification product of ermB and gene sequencing of ermB: With DL2000 Marker as the standard molecular, the amplification products of ermB were deteceted by $1.2 \%$ agarose gel electrophoresis. The PCR amplication products were recycled by DNA Fast Recovery kits and sequenced by Sangon Biotech (Shanghai) Co., Ltd.
Sequences analysis: It was finished by the analysis softwares BLAST and BioEdit in GenBank.

\section{RESULTS AND DISCUSSION}

Activities in vitro of macrolide antibiotics for isolates of pig Streptococcus: Clinical SS2 isolates from pigs can produce resistance to five macrolide antibiotics selected such as erythromycin, roxithromycin, azithromycin and tylosin. The drug-resistance rates of tilmicosin is $50 \%$ (20/40) and high rates in the other four antibiotics are respectively $80 \%(32 / 40), 77.5 \%(31 / 40), 80 \%(32 / 40)$ and $67.5 \%(27 / 40)$ (Table 2). For these five antibiotics, $\mathrm{MIC}_{50}$ are 8-64 $\mu \mathrm{g} \mathrm{mL}^{-1}$ and $\mathrm{MC}_{90}$ are $256 \mu \mathrm{g} \mathrm{mL}^{-1}$ which mainly centralized at high resistance area.

The amplification results of ermB, erm $A$ and mef $A$ : The chromosomal DNAs of 32 drug-resistant strains were amplified by PCR, 640 bp segement was detected in 32 isolates (Fig. 1), 421 bp segement in 7 isolates but no mefA was found in all isolates. The electrophoresis graphs of ermB and ermA genes of some strains, respectively are shown in Fig. 1 and 2.

The results of gene sequencing of ermB: Nucleotide sequences comparison showed that the ermB genes of 20 strains and the nucleotide sequences in the GenBank had the sequence similarity of $95 \sim 100 \%$, compared with strains in GenBank including Streptococcus suis (EU352644.1), Streptococcus pneumoniae (AJ972604.1), Tn2010 (EF592165.1), Enterococcus faecalis (U86375.1), Staphylococcus intermedius MLS-2 (AF239772.1), Streptococcus gallolyticus (AY183117.1), Streptococcus pyogenes (AJ972606.1), Enterococcus faecium (AY827542.1), Tn1545 (AM903082.1) and E. hirae (X81655.1). The analysis of homology results showed that ermB is exchanged widely among different isolates from pigs, human beings and other animals.

The sequence analysis of amino acid of ermB: Compared with the reference sequence of AJ972604.1, the amino acid sequences mutations of ermB in 20 strains were fewer which mainly included $\mathrm{Thr}$ to Ser mutation at the position 75, Ser to Asn at 100, Arg to his at 118 and Leu to Ile at 175. Ser to Asn mutation at position 100 and Arg to His mutation at position 118 of ermB were mainly detected in the 20 strains, among which all strains mutated at 100 and 13 strains mutated at 118 (Fig. 3). The ermB mutations at 100 and 118 were the same as the macrolide-resistant Streptococcus isolates from pigs and Streptococcus pneumoniae which were reported by Li et al. (2005) and Yao et al. (2004). 
Table 2: Activities in vitro of macrolide antibiotics for 40 isolates of Streptococcus suis serotype 2

\begin{tabular}{lccccc}
\hline Drugs & $\mathrm{MIC}$ ranges $\left(\mathrm{ug} \mathrm{mL} \mathrm{mL}^{-1}\right)$ & $\mathrm{MLC}_{50}\left(\mathrm{ug} \mathrm{mL}^{-1}\right)$ & $\mathrm{MLC}_{90}(\mathrm{ug} \mathrm{mL}$ & Resistant isolates (\%) & Susceptibial isolates (\%) \\
\hline Erythromycin & $0.01560-256$ & 64 & 256 & $32 / 40(80.0)$ & $8 / 40(20.0)$ \\
Roxithromycin & $0.01560-256$ & 64 & 256 & $31 / 40(77.5)$ & $9 / 40(22.5)$ \\
Tylosin & $0.03125-256$ & 64 & 256 & $32 / 40(80.0)$ & $8 / 40(20.0)$ \\
Azithromycin & $0.01560-256$ & 16 & 256 & $27 / 40(67.5)$ & $13 / 40(32.5)$ \\
Tilmicosin & $0.00780-256$ & 8 & 256 & $20 / 40(50.0)$ & $20 / 40(50.0)$ \\
\hline
\end{tabular}

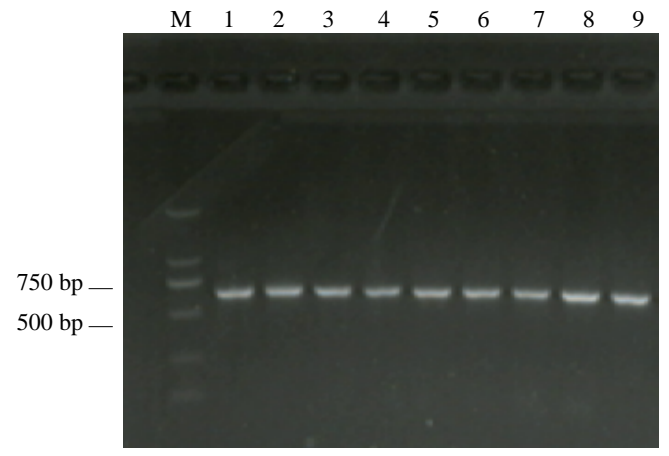

Fig. 1: The results of ermB genes by PCR; M: Maker; 1-9: ermB positive

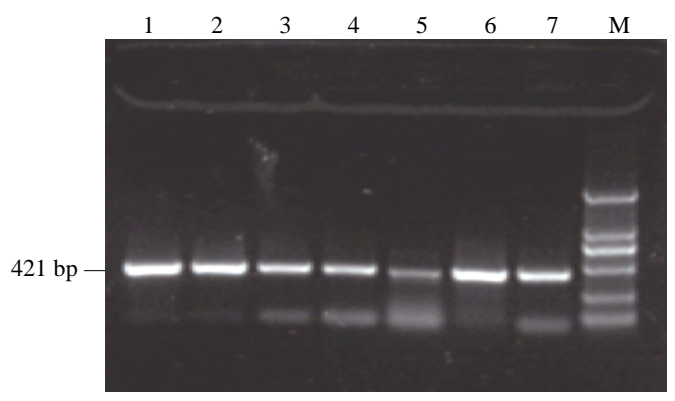

Fig. 2: The results of ermB genes by PCR; 1-7: ermA positive strain; M: Maker

Among the $32 \mathrm{SS} 2$ isolates resistant to macrolides, $100 \%(32 / 32)$ of them had the ermB and $21.88 \%(7 / 32)$ contained ermA but no mefA was detected in all strains. Both ermA and ermB genes detected rate was $21.88 \%$ (7/32). It showed that erythromycin resistance mechanism of SS2 isolates is mainly mediated by ermB and/or ermA in Hebei province which mediates the expression of erythromycin methylation transferase and the inner stype is the main one of drug-resistance which is similar to some research results (Tait-Kamradt et al., 2000). The proportion of $\mathrm{M}$ type is very low which is consistent with the findings by Martel et al. (2003).

Among the 32 Macrolide-resistant strains, ermB was detected in 16 isolates strains with high resistance $\left(\mathrm{MIC} \geq 64 \mu \mathrm{g} \mathrm{mL} \mathrm{m}^{-1}\right)$ and there were 7 strains with both ermB and ermA. It obviously showed that the isolates were highly resistant to macrolides if ermB alone or/and ermA were detected which was consistent with reporte of Li et al. (2005). However, the ermB was also detected

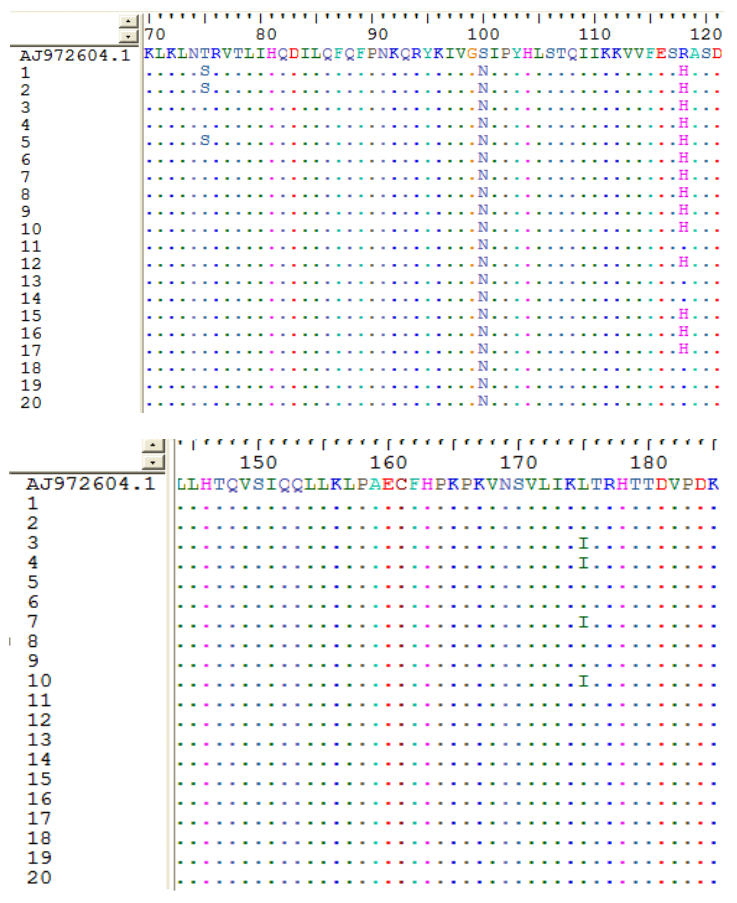

Fig. 3: Comparison of amino acid sequence of ermB (fragments involving mutational sites)

in another 4 strains with low resistance $\left(\mathrm{MIC}<8 \mu \mathrm{g} \mathrm{mL}^{-1}\right.$ ) which may be due to the expression level of ermB.

The amino acid sequences mutations of ermB in 20 strains were fewer which mainly include Thr to Ser at 75 , Ser to Asn at 100, Arg to his at 118 and Leu to Ile at 175. All of 20 strains mutated at 100 and 13 strains mutated at 118 (Fig. 3). What is more, the ermB mutations at 100 and 118 were the same as the macrolide resistant Streptococcus isolates from pigs and Streptococcus pneumoniae which were reported by Li et al. (2005) and Yao et al. (2004). Among 16 strains with high drugresistance and 4 low drug-resistant strains, there are one to three different amino acids. No obvious relationship between ermB resistant gene mutations and drug resistance was found.

\section{CONCLUSION}

The results of the sequence homology analysis showed that there were little differences of ermB in 20 
Streptococcus suis type 2 strains indicating that the primer sequence of ermB gene and the amino acid sequences with the activity of erythromycin methylation shift enzyme which is encoded by ermB are highly conservative.

The ermB genes of 20 strains and the nucleotide sequences in the GenBank had a high similarity with strains in GenBank including Streptococcus pneumoniae (AJ972604.1), Streptococcus gallolyticus (AY183117.1), Streptococcus pyogenes (AJ972606.1) and Enterococcus faecalis (U86375.1) which shows that ermB is exchanged widely among different isolates from pigs, human beings and other animals.

From the evolutionary tree of $\mathrm{ermB}$ gene, it can be concluded that there was a high sequences homology of $\operatorname{erm} B$ gene in the isolates from Tangshan, Zhangjiakou, Cangzhou in Hebei province. All the results showed that resistance gene of ermB existed widely and it was the main mechanism causing SS2 strains resistant to macrolides.

\section{ACKNOWLEDGEMENTS}

This research was supported by Hebei Science and Technology Support Program (09220402D), Natural Science Foundation of Hebei Province (C2009000877), Department of education project of Hebei (2008448).

\section{REFERENCES}

Li, X.Y., Z.H. Zhao, M. Yan, M. Yan, Y.J. Li and Y.H. Li, 2005. Mechanism of Streptococcus suis resistance to Macrolides in Northeast China. J. Preventive Vet. Med., 30: 612-617.

Martel, A., L.A. Devriese, A. Decostere and F. Haesebrouck, 2003. Presence of macrolide resistance genes in streptococci and enterococci isolated from pigs and pork carcasses. Int. J. Food Microbiol., 84: 27-32.

Sutcliffe, J., T. Grebe, A. Tait-Kamradt and L. Wondrack, 1996. Detection of erythromycin-resistant determinants by PCR. Antimicrob. Agents Chemother., 40: 2562-2566.

Tait-Kamradt, A., J. Clancy, M. Cronan, F. Dib-Hajj, L. Wondrack, W. Yuan and J. Sutcliffe, 1997. MefE is necessary for the erythromycin-resistant $M$ phenotype in Streptococcus neumoniae. Antimicrob. Agents Chemother., 41: 2251-2255.

Tait-Kamradt, A., T. Davies, P.C. Appelbaum, F. Depardieu and P. Courvalin et al., 2000. Two new mechanisms of macrolide resistance in clinical strains of Streptococcus pneumoniae from Eastern Europe and North America. Antimicrob. Agents Chemother., 44: 3395-3401.

Yao, C., Z.B. Yu and Y.H. Xiao, 2004. Study of macrolide resistant mechanism phenotypes and genotypes in Streptococcus pneumoniae. Chin. J. Clin. Pharmacol., 20: 266-269. 